\title{
Effects of Apatite Cement Containing Atelocollagen on Attachment to and Proliferation and Differentiation of MC3T3-E1 Osteoblastic Cells
}

\author{
Masaaki Takechi ${ }^{1}$, Yoshiaki Ninomiya ${ }^{1}, K_{\text {Kouji Ohta }}{ }^{1, *}$, Misato Tada ${ }^{1}$, Kazuki Sasaki $^{1}$, \\ Mohammad Zeshaan Rahman ${ }^{1}$, Akira Ohta ${ }^{1}$, Kanji Tsuru ${ }^{2}$ and Kunio Ishikawa ${ }^{2}$ \\ 1 Department of Oral and Maxillofacial Surgery, Division of Cervico-Gnathostomatology, \\ Programs for Applied Biomedicine, Graduate School of Biomedical Sciences, Hiroshima University, \\ Hiroshima 734-8553, Japan; takechi@hiroshima-u.ac.jp (M.T.); yn@hiroshima-u.ac.jp (Y.N.); \\ misatot@hiroshima-u.ac.jp (M.T.); sasaki@hiroshima-u.ac.jp (K.S.); md.zeshaan.rahman@gmail.com (M.Z.R.); \\ akira.ota.114@gmail.com (A.O.) \\ 2 Department of Biomaterials, Faculty of Dental Science, Kyushu University, Fukuoka 812-8582, Japan; \\ tsuru@dent.kyushu-u.ac.jp (K.T.); ishikawa@dent.kyushu-u.ac.jp (K.I.) \\ * Correspondence: otkouji@hiroshima-u.ac.jp; Tel.: +81-82-257-5673; Fax: +81-82-257-5671
}

Academic Editors: Xiaodong Huang and Jianhu Shen

Received: 19 November 2015; Accepted: 7 April 2016; Published: 13 April 2016

\begin{abstract}
To improve the osteoconductivity of apatite cement (AC) for reconstruction of bone defects after oral maxillofacial surgery, we previously fabricated AC containing atelocollagen (AC(ate)). In the present study, we examined the initial attachment, proliferation and differentiation of mouse osteoblastic cells (MC3T3-E1 cells) on the surface of conventional AC (c-AC), AC(ate) and a plastic cell dish. The number of osteoblastic cells showing initial attachment to $\mathrm{AC}$ (ate) was greater than those attached to c-AC and similar to the number attached to the plastic cell wells. We also found that osteoblastic cells were well spread and increased their number on $\mathrm{AC}(\mathrm{ate})$ in comparison with c-AC and the wells without specimens, while the amount of procollagen type I carboxy-terminal peptide (PIPC) produced in osteoblastic cells after three days on $\mathrm{AC}($ ate) was greater as compared to the others. There was no significant difference in regard to alkaline phosphatase (ALP) activity and osteocalcin production by osteoblastic cells among the three surface types after three and six days. However, after 12 days, ALP activity and the produced osteocalcin were greater with AC(ate). In conclusion, $\mathrm{AC}($ ate) may be a useful material with high osteoconductivity for reconstruction of bone defects after oral maxillofacial surgery.
\end{abstract}

Keywords: apatite cement; atelocollagen; osteoconductivity; MC3T3-E1 cell proliferation

\section{Introduction}

Hydroxyapatite (HAP: $\left.\mathrm{Ca}_{10}\left(\mathrm{PO}_{4}\right)_{6}(\mathrm{OH})_{2}\right)$ is widely used as a substitute material for the reconstruction of bone in oral maxillofacial surgery procedures [1,2]. However, a disadvantage of sintered HAP is difficulty with complete fitting of the shape to the bone defect [3]. Apatite cement (AC) was developed to overcome this disadvantage, as it sets to form HAP after mixing of the powder phase and liquid phase [4-6]. Thereafter, various types of AC were fabricated in an attempt to improve the properties in previous studies. Although conventional AC (c-AC) has some disadvantages, such as a long setting time of 30-60 min, fast-setting AC (fs-AC) can set within $5 \mathrm{~min}[7,8]$. Anti-washout AC (aw-AC) is stable and sets even when the paste is immersed in serum immediately after mixing $[9,10]$. Our previous report demonstrated that these three types of ACs have essentially the same levels of biocompatibility and osteoconductivity for proliferation and differentiation of osteoblasts in vivo [3]. Based on those findings, we considered that the ability of 
these ACs as the substitutes for reconstruction after oral maxillofacial surgery require improvement to provide for higher amounts of osteoconductivity.

Collagen is a primary component of bone and contributes mechanical properties that maintain the strength and structural integrity [11]. Furthermore, collagen has biological properties and demonstrates effects on cell differentiation, adhesion, growth and migration [12]. Atelocollagen is a type of soluble collagen produced from tropocollagen, the collagen molecule that makes up collagen fibrils, via the elimination of telopeptide moieties, which are considered to account for most of collagen's antigenicity [13].

In our previous study, we fabricated AC containing atelocollagen (AC(ate)) and examined soft tissue responses to $\mathrm{AC}$ and $\mathrm{AC}($ ate) in vivo. Those results showed a good soft tissue response in inflammatory conditions by $\mathrm{AC}($ ate) as compared to c-AC [14]. However, it remained unclear whether $\mathrm{AC}($ ate) has higher osteoconductivity than c-AC. In this study, we examined initial cell attachment, proliferation and differentiation of mouse osteoblastic cells (MC3T3-E1 cells) cultured on the surface of c-AC, AC(ate), as well as plastic cell culture wells used as a control.

\section{Results}

We found that the number of MC3T3-E1 cells initially attached to AC(ate) is greater than that of those to c-AC and was similar to the number attached to the plastic cell wells in Figure 1. Figure 2 shows that the number of MC3T3-E1 cells on the surface of each sample increased with incubation time, with those attached to AC(ate) rapidly increasing from Days 3-6, as compared to c-AC and the plastic wells. The adhered cells on the c-AC and AC(ate) after three days showed the typical osteoblast morphology, and these cells on $\mathrm{AC}$ (ate) were well spread as compared to those on c-AC, as shown in Figure 3. The cultured cells on AC(ate) were almost confluent in the cement bulk after six days (data not shown). The production of procollagen type I carboxy-terminal peptide (PIPC) and osteocalcin and the alkaline phosphatase (ALP) activities of MC3T3-E1 cells were determined as markers of differentiated osteoblasts. Figure 4 shows that the level of PIPC on AC(ate) was greater as compared to the plastic wells and c-AC on Day 3, after which PIPC production in all specimens decreased. However, on Day 12, the PIPC level with AC(ate) remained dramatically higher. There was no significant difference for ALP activity in the MC3T3-E1 cells among the three specimen types on Days 3 and 6, though a larger increase was found with $\mathrm{AC}$ (ate) as compared to the others on Day 12 in Figure 5. Similarly, as shown Figure 6, no significant difference in osteocalcin production was noted among the specimens on Days 3 and 6, while AC(ate) showed a greater increase as compared to the others from Days 9-12.

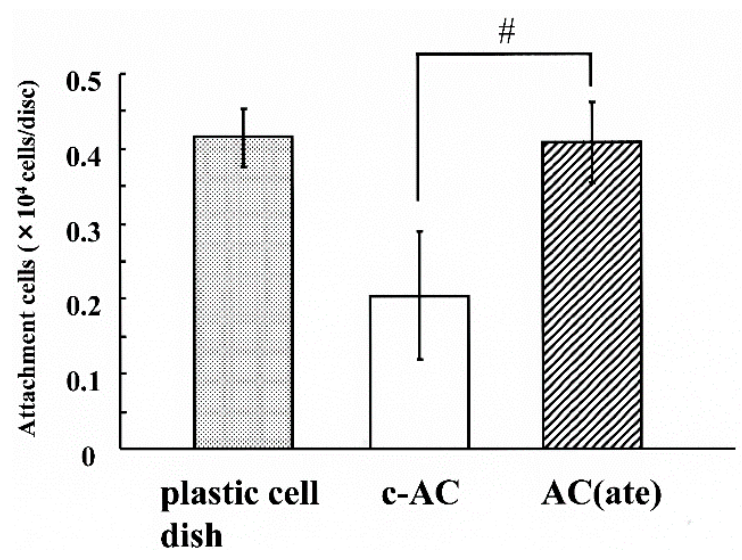

Figure 1. Initial attachment of cells to the surface of conventional apatite cement (c-AC), AC containing atelocollagen (AC(ate)) and plastic wells. The numbers of MC3T3-E1 cells with all of the specimens were determined after $5 \mathrm{~h}$ of culturing. Results are shown as the mean \pm standard deviation $(n=5)$. \# Significant difference as compared to c-AC (Student's $t$-test: $p<0.05)$. 


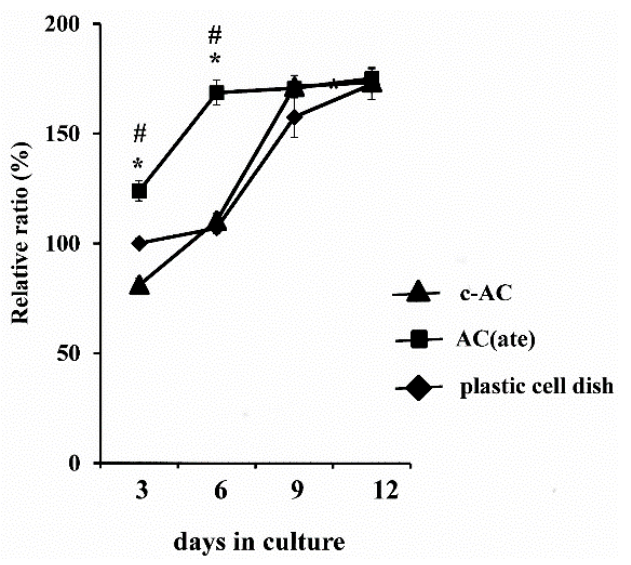

Figure 2. Proliferation of MC3T3-E1 cells on the surface of each type of specimen as evaluated by a methyl thiazolyl tetrazolium (MTT) assay. The results are shown as the mean \pm standard deviation $(n=5){ }^{*}$ and \# indicate a significant difference as compared to plastic cell well and c-AC, respectively (Student's $t$-test: $p<0.05)$.

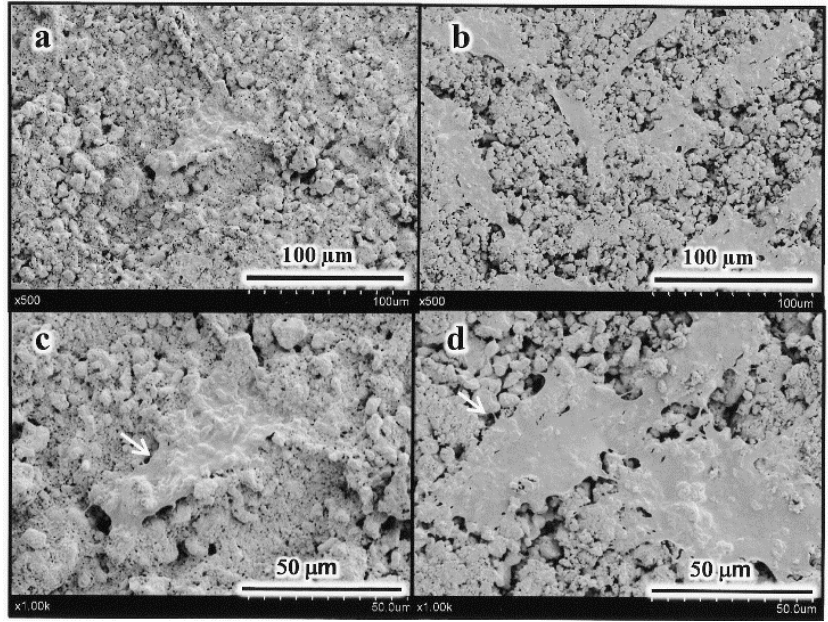

Figure 3. Typical scanning electron microscope (SEM) images of the surfaces for $(\mathbf{a}, \mathbf{c}) \mathrm{c}-\mathrm{AC}$ and $(\mathbf{b}, \mathbf{d}) \mathrm{AC}($ ate) after cell culturing for three days. Original magnification lower $(\mathbf{a}, \mathbf{b})$ and higher $(\mathbf{c}, \mathbf{d})$.

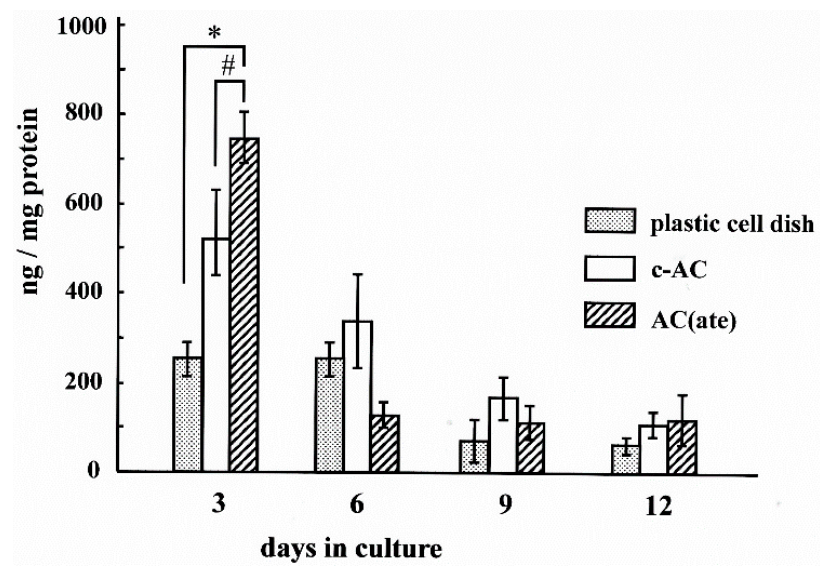

Figure 4. Time course of the amount of procollagen type I carboxy-terminal peptide (PICP) produced by MC3T3-E1 cells in cultures with each type of specimen. Results are shown as the mean \pm standard deviation $(n=5) .{ }^{*}$ and \# indicate a significant difference as compared to the plastic cell well and c-AC, respectively (Student's $t$-test: $p<0.05)$. 


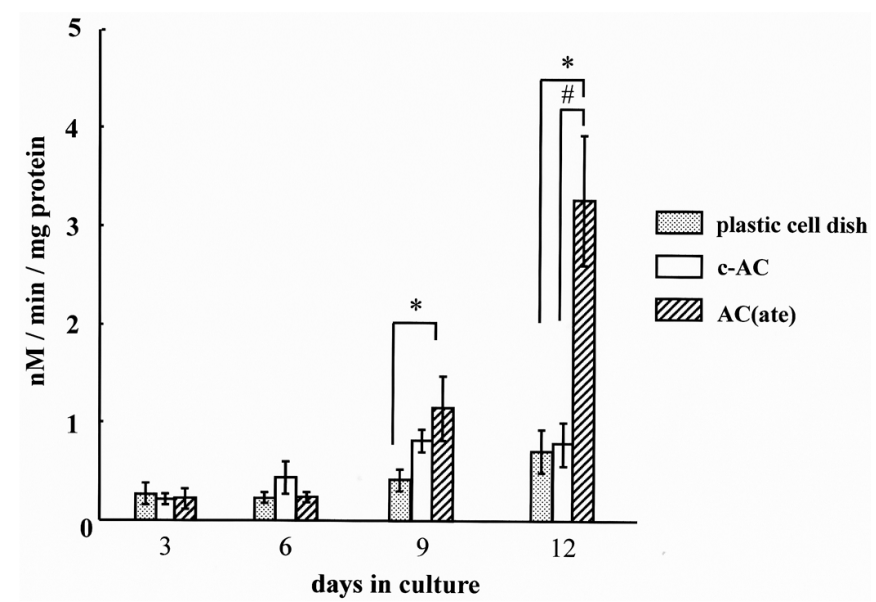

Figure 5. Time course of alkaline phosphatase (ALP) activity by MC3T3-E1 cells in cultures with each type of specimen. Results are shown as the mean \pm standard deviation $(n=5) .{ }^{*}$ and \# indicate a significant difference as compared to the plastic cell well and c-AC, respectively (Student's $t$-test: $p<0.05)$.

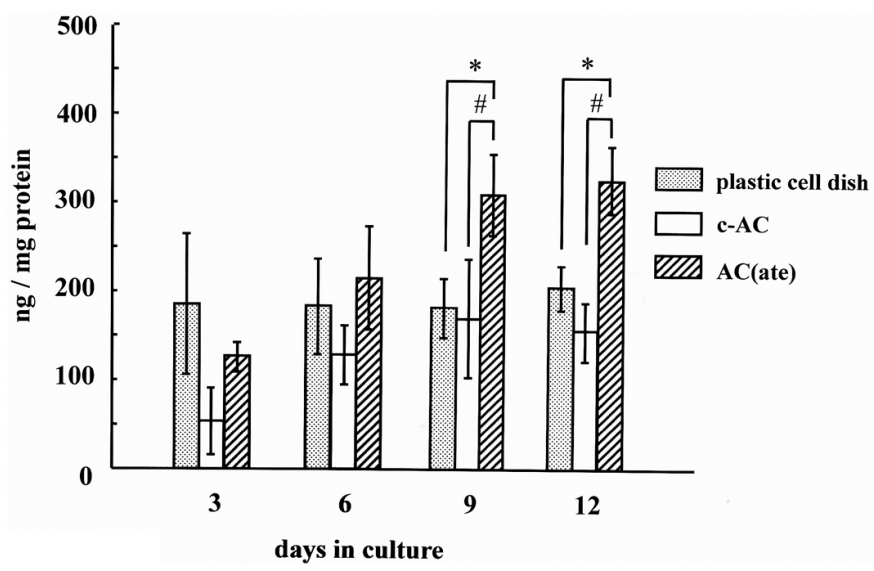

Figure 6. Time course of the amount of osteocalcin produced by MC3T3-E1 cells in cultures with each type of specimen. Results are shown as the mean \pm standard deviation $(n=5) .{ }^{*}$ and \# indicate a significant difference as compared to the plastic cell well and c-AC, respectively (Student's $t$-test: $p<0.05)$.

\section{Discussion}

Atelocollagen is a type of collagen obtained from antigenic telopeptides and considered to be preferable for biomaterial use as compared to other types of collagen, because of its low level of antigenicity [11]. Collagen has been reported to accelerate the regeneration and osteoconduction of cementum when used as a coating material with calcium phosphate ceramics and tricalcium phosphate [15]. Miyamoto et al. fabricated AC containing atelocollagen and examined the basic properties of AC with atelocollagen content from $0.5 \%$ to $5 \%$. They found that $2 \%$ content or over of atelocollagen improved the handling properties, was more adhesive and is desirable for its use in surgical procedures. However, the addition of atelocollagen to AC has disadvantages, such as a decrease of diametral tensile strength (DTS) and an increase of setting time [16]. From those results, the optimal additional concentration of atelocollagen in AC for surgical applications was decided to be $2 \%$, and our group investigated the response of soft tissue and bone to AC containing $2 \%$ atelocollagen $(\mathrm{AC}($ ate) $)$ in vivo and found that the inflammatory reaction around $\mathrm{AC}(\mathrm{ate})$ in rat abdominal skin was lower than that around $\mathrm{c}-\mathrm{AC}$, while new bone formation around $\mathrm{AC}(\mathrm{ate})$ by rat tibia bone was greater than that observed around c-AC [14]. In the present in vitro study, we demonstrated that initial 
attachment, proliferation and differentiation of osteoblastic cells on $\mathrm{AC}($ ate) were greater as compared to $\mathrm{c}-\mathrm{AC}$.

Initial cell attachments, as well as proliferations on an AC surface are important factors for the osteoconduction in bone defects. In our previous studies, we noted that the number of cells initially attached to c-AC, fs-AC and aw-AC was lower as compared to plastic cell wells, whereas the cell proliferation among those specimens was similar [3]. In the present study, the number of cells showing initial attachment to $\mathrm{AC}($ ate) was greater as compared to $\mathrm{AC}$ and similar to the numbers attached to the plastic wells. Thereafter, the number of cells on $\mathrm{AC}(\mathrm{ate})$ rapidly increased as compared to c-AC and the wells. Collagen specifically binds cell-surface cellular adhesion molecules, such as integrins, which enhance the cell adhesion and proliferation of osteoblasts via various signal transduction factors [17]. Furthermore, collagen may also function in a matrix in which particles of calcium phosphate ceramic, such as hydroxyapatite, are anchored [14]. We concluded that $\mathrm{AC}$ (ate) may promote osteoblastic adhesion and proliferation from host bone in bone defects, along with providing the basic properties of atelocollagen.

Procollagen type I carboxy-terminal peptide (PICP), ALP and osteocalcin are known as markers of osteoblast cell differentiation. PICP is released from osteoblasts during the early differentiation stage when type I collagen is synthesized into bone [18], while ALP and osteocalcin are mid- and late-stage markers, respectively, of cell differentiation [19]. Previously, our group found that the levels of these differentiation markers in cultures with c-AC, fs-AC and aw-AC were similar, while they were higher than cultures with a plastic dish and sintered-HAP at each stage, indicating that these AC formulations have a greater ability to enhance the differentiation of osteoblasts [3]. Type 1 collagen promotes various processes during osteoblast differentiation, such as ALP activity, expression of non-collagenous extracellular matrix proteins and deposition of minerals into the matrix [12]. In the present study, we found that the expression of cell differentiation markers in cultures with $\mathrm{AC}$ (ate) were significantly higher as compared to $\mathrm{AC}$ and the plastic wells at each stage, indicating an interaction among HAP, bone mineral components, the bone extracellular matrix and collagen to accelerate osteoblastic cell differentiation. On the other hand, collagen and HAP enhance the morphological differentiation of osteoclasts [20], while the extracellular matrix containing collagen fibers formed by osteoblasts was reported to promote osteoclastic resorption of calcium phosphate ceramics in vitro [21]. Therefore, $\mathrm{AC}(\mathrm{ate})$ may augment bone regeneration by promoting differentiation of host osteoblasts and osteoclasts during the remodeling process, indicating its usefulness as a material with high osteoconductivity for reconstruction of bone defects after oral maxillofacial surgery.

\section{Materials and Methods}

\subsection{Preparation of AC Containing Atelocollagen}

The powder phase of $\mathrm{AC}($ ate), an equimolar mixture of tetracalcium phosphate (TTCP: $\left.\mathrm{Ca}_{4}\left(\mathrm{PO}_{4}\right)_{2} \mathrm{O}\right)$ and dicalcium phosphate anhydrous $\left(\mathrm{DCPA}: \mathrm{CaHPO}_{4}\right)$, was prepared as described previously. Neutral sodium hydrogen phosphate (pH 7.4) was made by mixing $0.2 \mathrm{~mol} / \mathrm{L} \mathrm{Na}_{2} \mathrm{HPO}_{4}$ with $0.2 \mathrm{~mol} / \mathrm{L} \mathrm{NaHPO}_{4}$, with the resulting solution showing $\mathrm{pH} 7.4$ at $37^{\circ} \mathrm{C}$. A $2 \%$ atelocollagen solution (atelocollagen, from calf corium, Koken, Tokyo, Japan) containing those $\mathrm{Na}_{2} \mathrm{HPO}_{4}$ solutions was used as the liquid phase of $\mathrm{AC}(\mathrm{ate})$. As for c-AC, we used distilled water as the liquid phase. The powder and liquid phases were mixed with a spatula at a powder to liquid ratio (P/L ratio) of 3.5. The obtained paste was packed into a plastic mold (diameter of $10 \mathrm{~mm}$ ) at a pressure of approximately 1.0 MPa under constant vibration (Automatic Labo-Mixer NS-8, Iuchi, Osaka, Japan) and allowed to harden in an incubator at $37{ }^{\circ} \mathrm{C}$ with $100 \%$ relative humidity for $24 \mathrm{~h}$. The discs were then polished to a thickness of $200 \mu \mathrm{m}$. 


\subsection{Cells and Incubation Condition}

MC3T3-E1 cells were used as previously described [3] and cultured in alpha-modified minimum essential medium (Dainihonseiyaku, Osaka, Japan) supplemented with $50 \mu \mathrm{g} / \mathrm{mL}$ ascorbic acid, $2 \mathrm{mmol} / \mathrm{L} \beta$-glycerophosphate (Sigma Chemical Co., St. Louis, MO, USA) and 10\% fetal bovine serum (Whittaker Bioproducts, Inc., Walkerville, MO, USA). Each disc was placed in a plastic well (48-well cell-cultured cluster, Corning, NY, USA); then, $500 \mu \mathrm{L}$ of culture medium containing a cell suspension at concentration of $1 \times 10^{3}$ cells per $10 \mathrm{~mm}$ disc was gently poured onto each disc, as well as into empty plastic wells as the control. After $5 \mathrm{~h}, 2 \mathrm{~mL}$ of medium were added to each well, and the samples were incubated in an atmosphere containing $5 \% \mathrm{CO}_{2}$ at $37^{\circ} \mathrm{C}$.

\subsection{Initial Cell Attachment and Proliferation of MC3T3-E1 Cells with $c-A C$ and $A C(a t e)$}

The number of MC3T3-E1 cells attached to each disc or empty well was determined as follows. Following the initial 5-h incubation, the specimens were washed with $0.1 \mathrm{~mol} / \mathrm{L}$ phosphate buffer saline (PBS) to eliminate non-adherent cells, then adherent osteoblasts were harvested using PBS containing $0.1 \%$ collagenase and trypsin and counted using a hemocytometer.

Cell proliferation was then determined after 3, 6, 9 and 12 days of incubation using a methyl thiazolyl tetrazolium (MTT) assay. MTT reagent (3-[4,5-dimetylthiazole-2-yl]-2,5-diphenyltetrazolium bromide), which is enzymatically converted by living cells into a blue/purple formazan product, was added to each sample and incubated at $37^{\circ} \mathrm{C}$ for $4 \mathrm{~h}$. The blue formazan product was solubilized with dimethylsulfoxide, and the liquid portion of each sample was removed for the assay, which was performed in a 96-well plate. Absorbance was read using a microplate reader (MTP-32 Microplate Reader, Corona elect, Ibaragi, Japan) at $570 \mathrm{~nm}$.

The cell morphology adhered on the specimens was observed by a scanning electron microscope (SEM, S-3400N, Hitachi High-Technologies Co., Tokyo, Japan) at $5 \mathrm{kV}$ of accelerating voltage after the fixation and dehydration followed by gold-palladium coating (magnetron sputtering machine; MSP-1S, Vacuum Device Co., Ibaraki, Japan).

\subsection{Alkaline Phosphatase Activity in MC3T3-E1 Cells with c-AC and AC(ate)}

The ALP activity of the osteoblasts was determined using an enzyme-linked immunosorbent assay (ELISA) with p-nitrophenyl phosphate as the substrate (ALP substrate system, Kirkegaard \& Perry Lab., Gaithersburg, MD, USA). The absorbance of $p$-nitrophenol at $405 \mathrm{~nm}$ was determined with a plate reader (MTP-32 Microplate Reader, Corona elect, Ibaragi, Japan). Enzymatic activity is expressed as nmol of p-nitrophenol/minute per mg of protein. Protein content was determined by the method of Bradford using bovine r-globulin as the standard [22].

\subsection{Production of Procollagen Type I Carboxy-Terminal Peptide and Osteocalcin in MC3T3-E1 Cells with c-AC and $A C($ ate $)$}

PICP and osteocalcin were analyzed according to the method of Yuasa et al. [3]. Each specimen was decalcified with $0.6 \mathrm{~N} \mathrm{HCl}$ for $30 \mathrm{~min}$, then the resulting solutions were harvested and stored at $-20{ }^{\circ} \mathrm{C}$ until the assay. The amounts of PICP and osteocalcin were measured using a Procollagen Type I C peptide EIA kit and Osteocalcin EIA kit, respectively (Takara, Shiga, Japan). Each experiment for measurements of ALP activity, PICP protein levels and osteocalcin level was performed in triplicate and repeated 3 times.

\subsection{Statistical Analysis}

Data were analyzed using Student's $t$-test or one-way analysis of variance (ANOVA), and the results are presented as the mean \pm standard deviation. 


\section{Conclusions}

The addition of atelocollagen to AC has been reported to provide some advantages, such as improvement in handling properties and adhesive properties when used for surgical applications, and soft tissue showed a good inflammatory response. In the present study, $\mathrm{AC}($ ate) increased initial attachment, proliferation and differentiation of osteoblasts in comparison with c-AC. We consider $\mathrm{AC}(\mathrm{ate})$ to be a useful material with high osteoconductivity for reconstruction of bone defects after oral maxillofacial surgery.

Acknowledgments: This investigation was supported, in part, by a Grant-in-Aid for Scientific Research from the Ministry of Education, Science, Sports and Culture, Japan.

Author Contributions: Masaaki Takechi, Kanji Tsuru and Kunio Ishikawa conceived of and designed the experiments. Yoshiaki Ninomiya, Misato Tada and Kazuki Sasaki performed the experiments. Mohammad Zeshaan Rahman and Kouji Ohta analyzed the data. Kanji Tsuru and Kouji Ohta wrote and revised the manuscript. Masaaki Takechi, Kanji Tsuru and Kouji Ohta discussed the experiments and the manuscript.

Conflicts of Interest: The authors declare no conflict of interest.

\section{References}

1. Kent, J.N.; Quinn, J.H.; Zide, M.F.; Guerra, L.R.; Boyne, P.J. Alveolar ridge augmentation using nonresorbable hydroxylapatite with or without autogenous cancellous bone. J. Oral Maxillofac. Surg. 1983, 41, 629-642. [CrossRef]

2. Brook, I.M.; Lamb, D.J. The use of particulate and block forms of hydroxylapatite for alveolar augmentation. Int. J. Oral Maxillofac. Implant. 1987, 2, 85-89.

3. Yuasa, T.; Miyamoto, Y.; Ishikawa, K.; Takechi, M.; Momota, Y.; Tatehara, S.; Nagayama, M. Effect of apatite cements on proliferation and differentiation of human osteoblasts in vitro. Biomaterials 2004, 25, 1159-1166. [CrossRef] [PubMed]

4. Brown, W.E.; Chow, L.C. A new calcium phosphate, water-setting cement. In Cements Research Progress; Brown, P.W., Ed.; American Ceramic Society: Westerville, OH, USA, 1986; pp. 351-379.

5. Brown, W.E.; Chow, L.C. Combinations of Sparingly Soluble Calcium Phosphates in Slurries and Paste as Mineralizers and Cements. U.S. Patent US RE33161 E, 6 February 1990.

6. Chow, L.C. Development of self-setting calcium phosphate cements. J. Ceram. Soc. Jpn. 1991, 99, 954-964. [CrossRef]

7. Miyamoto, Y.; Ishikawa, K.; Takechi, M.; Toh, T.; Yoshida, Y.; Nagayama, M.; Kon, M.; Asaoka, K. Tissue responses to fast setting calcium phosphate cement in bone. J. Biomed. Mater. Res. 1997, 37, 457-464. [CrossRef]

8. Miyamoto, Y.; Ishikawa, K.; Fukao, H.; Sawada, M.; Nagayama, M.; Kon, M.; Asaoka, K. In vivo setting behaviour of fast-setting calcium phosphate cement. Biomaterials 1995, 16, 855-860. [CrossRef]

9. Miyamoto, Y.; Ishikawa, K.; Takechi, M.; Yuasa, M.; Kon, M.; Nagayama, M.; Asaoka, K. Non-decay type fast-setting calcium phosphate cement: Setting behaviour in calf serum and its tissue response. Biomaterials 1996, 17, 1429-1435. [CrossRef]

10. Takechi, M.; Miyamoto, Y.; Ishikawa, K.; Yuasa, M.; Nagayama, M.; Kon, M.; Asaoka, K. Non-decay type fast-setting calcium phosphate cement using chitosan. J. Mater. Sci. Mater. Med. 1996, 7, 317-322. [CrossRef]

11. Miyata, T.; Taira, T.; Noishiki, Y. Collagen engineering for biomaterial use. Clin. Mater. 1992, 9, $139-148$. [CrossRef]

12. Lynch, M.P.; Stein, J.L.; Stein, G.S.; Lian, J.B. The influence of type collagen on the development and maintenance of the osteoblast phenotype in primary and passaged rat calvarial osteoblasts: Modipcation on expression of genes supporting cell growth, adhesion, and extracellular matrix mineralization. Exp. Cell Res. 1995, 216, 35-45. [CrossRef] [PubMed]

13. Hanai, K.; Kojima, T.; Ota, M.; Onodera, J.; Sawada, N. Effects of atelocollagen formulation containing oligonucleotide on endothelial permeability. Drug Deliv. 2012, 2012. [CrossRef] [PubMed]

14. Takechi, M.; Miyamoto, Y.; Ishikawa, K.; Momota, Y.; Yuasa, T.; Tatehara, S.; Takano, H.; Minamiguchi, S.; Nagayama, M. Histological evaluation of apatite cement containing atelocollagen. Dent. Mater. J. 2007, 26, 194-200. [CrossRef] [PubMed] 
15. Sugaya, A.; Minabe, M.; Tamura, T.; Hori, T.; Tatsumi, J.; Watanabe, Y.; Ikeda, K.; Numabe, Y.; Hayashi, H.; Kamoi, K. Effects on wound healing of tricalcium phosphate-collagen complex implants in periodontal osseous defects in the dog. J. Periodontal Res. 1990, 25, 60-63. [CrossRef] [PubMed]

16. Miyamoto, Y.; Ishikawa, K.; Takechi, M.; Toh, T.; Yuasa, T.; Nagayama, M.; Suzuki, K. Basic properties of calcium phosphate cement containing atelocollagen in its liquid or powder phases. Biomaterials 1998, 19, 707-715. [CrossRef]

17. Takeuchi, Y.; Nakayama, K.; Matsumoto, T. Differentiation and cell surface expression of transforming growth factor-b receptors are regulated by interactions with matrix collagen in murine osteoblastic cells. J. Biol. Chem. 1996, 271, 3938-3944. [PubMed]

18. Stein, G.S.; Lian, J.B.; Owen, T.A. Relationship of cell growth to the regulation of tissue-specific gene expression during osteoblast differentiation. FASEB J. 1990, 4, 111-123.

19. Shu, R.; McMullen, R.; Baumann, M.J.; McCabe, L.R. Hydroxyapatite accelerates differentiation and suppresses growth of MC3T3-E1 osteoblasts. J. Biomed. Mater. Res. 2003, 67, 1196-1204. [CrossRef] [PubMed]

20. Gilles, J.A.; Carnes, D.L.; Windeler, A.S. Development of an in vitro culture system for the study of osteoclast activity and function. J. Endod. 1994, 20,327-331. [CrossRef]

21. De Bruijn, J.D.; Bovell, Y.P.; Davies, J.E.; van Blitterswijk, C.A. Osteoclastic resorption of calcium phosphates is potentiated in postosteogenic culture conditions. J. Biomed. Mater. Res. 1994, 28, 105-112. [CrossRef] [PubMed]

22. Bradford, M.M. A rapid and sensitive method for the quantitation of microgram quantities of protein utilizing the principle of protein-dye binding. Anal. Biochem. 1976, 72, 248-254. [CrossRef]

(C) 2016 by the authors; licensee MDPI, Basel, Switzerland. This article is an open access article distributed under the terms and conditions of the Creative Commons Attribution (CC-BY) license (http:/ / creativecommons.org/licenses/by/4.0/). 